This is the peer reviewed version of the following article: Bond David, Bugeja Martin, and Czernkowski Robert 2012, 'Did Australian firms choose to switch to reporting operating cash flows using the indirect method?', Wiley-Blackwell Publishing Asia, vol. 22, no. 1, pp. 18-24. which has been published in final form at http://dx.doi.org/10.1111/j.18352561.2011.00156.x This article may be used for non-commercial purposes in accordance With Wiley Terms and Conditions for self-archiving' 


\title{
Did Australian firms choose to switch to reporting operating cash flows using the indirect method?
}

\author{
by \\ David Bond \\ University of Technology, Sydney \\ Martin Bugeja* \\ University of Technology, Sydney \\ Robert Czernkowski \\ University of Technology, Sydney
}

\begin{abstract}
In 2007 Australian accounting standards were amended to allow a choice of presenting operating cash flows using either the direct or indirect method. This study investigates the number of ASX listed entities that switched to the indirect format. Our results indicate that between 2007 and 2009 nine companies changed their reporting format. The firms adopting the indirect method have similar leverage, liquidity and performance to industry and size matched controls. Given that previous research indicates that the direct method provides superior information for predicting cash flows and performance our results will be welcomed by financial statement users and the AASB.
\end{abstract}

JEL classification codes: M40, M41

\footnotetext{
* Corresponding author: Martin Bugeja, Accounting Discipline Group, University of Technology Sydney, PO Box 123, Broadway, New South Wales, 2007, Australia. Telephone + 6129514 3743, fax + 61295143669. E-mail address: martin.bugeja@uts.edu.au David Bond, Martin Bugeja and Robert Czernkowski are at The University of Technology, Sydney. Martin Bugeja and Robert Czernkowski are CPA members of CPA Australia. The authors acknowledge the helpful comments from two anonymous referees and the research assistance of Raghav Jain.
} 


\section{Background}

There are two methods for presenting operating cash flows (OCF). Under the direct format the cash flow statement presents the actual cash flows from various types of operating activities (e.g., collections from customers, payments to suppliers or taxes paid). In contrast, the indirect format provides a reconciliation between net income after tax and cash flow from operations. With the indirect format financial statement users need to interpolate from the data provided to estimate actual cash flows.

Immediately prior to Australia’s adoption of International Financial Reporting Standards (IFRS) in 2005 the applicable Australian accounting standard was AASB 1026 Statement of Cash Flows. AASB 1026 required that OCF be presented on the cash flow statement using the direct method (paragraph 6.1), with a reconciliation between OCF and profit after tax (i.e., indirect method) provided in the notes (paragraph 6.2). The standard recommended the use of the direct method on the basis that the direct method 'provides information that is not otherwise available in the balance sheet and profit and loss account.' Further, the standard argued that the direct method 'provided a more useful basis for estimating future cash flows than a method of presentation that discloses only the net amount of cash flows arising from operating activities’ (paragraph 6.2.2).

Upon the adoption of IFRS by Australia in 2005 the applicable accounting standard was AASB 107 Cash Flow Statements which was equivalent to IAS 7 Cash Flow Statements. ${ }^{1}$ Indicative of the Australian Accounting Standards Board's (AASB) preference for reporting OCF using the direct method, the Australian version of the international standard deleted paragraph 18(b) of IAS 7 which allowed a choice between the direct and indirect method of

\footnotetext{
${ }^{1}$ For financial years commencing on or after 1 July 2009, AASB 107 was reissued and renamed "Statement of Cash Flows.” Similarly IAS 107 was also renamed "Statement of Cash Flows.”
} 
presenting OCF. Furthermore, paragraph Aus 20.1 was included in AASB 107 to require a reconciliation between OCF and net profit after tax.

In April 2007, the AASB amended AASB 107 pursuant to AASB 2007-4 Amendments to Australian Accounting Standards. AASB 2007-4 was implemented to remove differences between IFRS and the standards adopted in Australia. As a consequence of AASB 2007-4 a choice between presenting OCF using either the direct or indirect method was introduced in Australia. This choice was available for periods commencing on or after 1 July 2007 with early adoption permitted. The revised version of AASB 107 provides a distinct preference for the direct method with paragraph 19 stating 'entities are encouraged to report cash flows from operating activities using the direct method. The direct method provides information which may be useful in estimating future cash flows and which is not available under the indirect method.' Under this revised standard firms that choose to present OCF using the direct method continue to need to present a reconciliation between net profit and OCF in the notes to the accounts (paragraph. Aus20.1). Interestingly there is no requirement in the standard for firms using the indirect method of presentation on the face of the cash flow statement to present the direct method in the notes. As discussed by Bradbury (2011), a current joint Exposure Draft which aims to harmonise the adoption of IFRS in Australia and New Zealand would have the effect of introducing the choice between the direct and indirect methods of presenting OCF into the New Zealand equivalent of IFRS. ${ }^{2}$ In addition, it would also result in the deletion of paragraph Aus 20.1 from AASB 107 meaning that Australian entities presenting OCF using the direct method would no longer be required to provide the indirect method reconciliation.

\footnotetext{
${ }^{2}$ AASB Exposure Draft 200A and Financial Reporting Standards Board of the New Zealand Institute of Chartered Accountants Exposure Draft 121, "Proposals to harmonise Australian and New Zealand Standards in relation to entities applying IFRSs as adopted in Australia and New Zealand.”
} 
The purpose of this study is to provide evidence on the number of Australian listed entities reporting using Australian accounting standards that made the choice to present OCF using the indirect method. As prior to 2007 Australian accounting standards consistently required the use of the direct method of presenting OCF, firms would have put in place reporting systems that captured the data needed to report OCF on a direct basis. The move to an indirect presentation format cannot therefore be justified using the argument that the direct method imposed additional data collection costs on the firm (e.g., Brahmasrene, Strupeck and Whitten, 2004; Goyal, 2004). One possible reason why a firm may make the choice to change presentation formats is if they believe that the purpose of the cash flow statement is to link the balance sheet and income statement by providing a reconciliation of profit after tax with CFO (Wallace, Choudhury and Pendlebury, 1997; Brahmasrene, Strupeck and Whitten, 2004). Goyal (2004) suggests that firms may prefer the indirect method if the use of the direct method discloses commercially sensitive information.

Using data for the 2007, 2008 and 2009 financial years the results indicate that only nine companies made the choice to present OCF using the indirect method. Additionally, a comparison of these companies to a control group matched within industry by size finds no significant differences in leverage, performance and liquidity. These findings would be welcomed by the AASB as they indicate that Australian firms are continuing to report OCF using the preferred reporting format. It also suggests that if ED 121 is adopted in New Zealand the expectation would be that only a small number of companies will chose to move from the direct to the indirect method of presenting OCF. The results also stand in contrast to findings in the US (Krishnan and Largay, 2000; Orpurt and Zang, 2009) and UK (Wallace, Choudhury and Adhikari, 1999) that indicate that when firms are provided with a choice between reporting formats for OCF the vast majority of firms typically use the indirect method. The difference in the rate of usage of the indirect method in Australia is likely 
explained by Australian firms having already established reporting systems to collect direct OCF information.

The remainder of this study is arranged as follows. The next section reviews prior literature discussing the usefulness of cash flows presented using the direct and indirect method.

Section three discusses data collection and results. The final section of the paper provides a conclusion.

\section{Prior literature}

Similar to the current accounting requirements in Australia, SFAS 95 Statement of Cash Flows in the United States of America (US) allows a choice between the direct and indirect method of reporting OCF. Firms that opt to use the direct method must also provide a reconciliation between OCF and net profit after tax (paragraph 29). The Financial Accounting Standards Board (FASB) however expresses a preference for OCF to be presented using the direct method (paragraph 27). Prior research indicates that only a very small proportion of US firms (approximately 2-3\%) choose to report their OCF using the direct method (Krishnan and Largay, 2000; Orpurt and Zang, 2009). A choice between the direct and indirect methods was also allowed in the United Kingdom (UK) under FRS 1 Cash Flow Statements (paragraph 7). Where the direct method of presentation was used, a reconciliation between net profit and OCF was also required (paragraph 12). A low use of the direct method is reported for the UK by Wallace, Choudhury and Adhikari (1999).

Surveys of both internal and external users of accounting information typically support the use of the direct OCF presentation method. These surveys include those both in Australia (Jones, Romano and Smyrnios, 1995; Jones and Ratnatunga, 1997; Jones, Sharma and Mock, 1998; Goyal, 2004) and overseas (McEnroe, 1996). An exception to these findings however is presented in Brahmasrene, Strupeck and Whitten (2004). 
Evidence from previous academic research indicates that OCF information presented using the direct format provides superior information for predicting future cash flows and earnings (e.g., Krishnan and Largay, 2000; Orpurt and Zang, 2009; Arthur, Cheng and Czernkowski, 2010). Furthermore, capital markets research indicates that the association between share prices and returns is higher for cash flow information presented using the direct format (e.g., Clinch, Sidhu and Sin, 2002; Orpurt and Zang, 2009). A more thorough discussion of these studies is provided in the recent paper by Bradbury (2011).

Despite a preference for the direct method being expressed in surveys of users and being supported by academic research there are those that argue for the use of the indirect method. One argument often raised in support of the indirect method is that it is possible to calculate cash flows indirectly using the income statement and successive balance sheets. However, prior research indicates that there are often material non-articulation differences between reported actual cash flows and implied cash flows from using the income statement and balance sheet changes (e.g., Bahnson, Miller and Budge, 1996; Krishnan and Largay, 2000; Opurt and Zang, 2009). Again, a more thorough description of these studies is given by Bradbury (2011). Proponents of the indirect method also argue that preparing information using the direct method imposes additional reporting costs on organisations (Wallace, Choudhury and Adhikari, 1999; Krishnan and Largay, 2000) and may result in the disclosure of sensitive information. Furthermore, it is also argued that the purpose of the cash flow statement is to explain the difference between profit and operating cash flows, justifying the indirect approach (Wallace, Choudhury and Adhikari, 1999; Krishnan and Largay, 2000).

\section{Data collection and results}

The Aspect FinAnalysis database was used to identify all entities listed on the Australian Securities Exchange (ASX) during the years 2006 through 2009 inclusive. The financial 
report for each entity was downloaded from the Aspect Huntley FinAnalysis database and then manually checked to ascertain which format was used for the presentation of OCF on the cash flow statement. This number of firms using the indirect format to report OCF was respectively 23, 34, 41 and 44 for each of the years 2006 through 2009. For each entity using the indirect method the statement of accounting policies in the notes to the accounts was read to determine if the entity was using Australian accounting standards. As would be expected all the firms using the indirect method in 2006 prepared their accounts using non-Australian accounting standards. In 2007, three companies using Australian accounting standards decided to make an early adoption of AASB 2007-4 and changed their OCF presentation format to the indirect method. An additional six companies made the switch in 2008. In 2009, these nine companies continued using the indirect method to disclose OCF with no additional companies electing to make the change. Overall, our results therefore indicate that the vast majority of Australian firms have retained the disclosure of OCF using the direct method. This result is perhaps not unexpected as disclosure practices tend to be "sticky" over time particularly as firms would already have implemented reporting systems to collect direct cash flow data. A summary of this data collection process is provided in Table 1.

\section{INSERT TABLE 1 HERE}

Table 2 presents the names and industry identification of the companies using Australian accounting standards that chose to switch to the OCF presentation method. The companies changing their disclosure policy come from a broad range of industries and include some of Australia’s largest companies: BHP Billiton Limited, Amcor Limited and Woodside Petroleum Limited.

INSERT TABLE 2 HERE 
Only two companies that made the switch in reporting method explained the rationale for the change in the notes to the accounts. Woodside Petroleum Limited stated:

“The Group believes that the indirect method of presenting cash flows provides more relevant information as it results in increased comparability of the Group’s Cash Flow Statement with those of its peer group.”3 As our analysis indicates that very few companies using Australian accounting standards switched to the indirect method Woodside Petroleum Ltd must be using foreign companies as the comparison group. BHP Billiton Limited also explained their decision to use the indirect method by indicating "this change in presentation more effectively conveys the relationship between its financial performance and operating cash flows." 4 It thus appears that from the viewpoint of BHP Billiton Limited the purpose of the operating section of the cash flow statement is to explain how OCF differs to net profit. We contacted the remaining seven companies to request an explanation for why the company chose to switch their method of presenting OCF. ${ }^{5}$ At the time of writing this paper we had not received a response from any of the companies.

Using UK data Wallace, Choudhury and Adhikari (1999) examine whether the comprehensiveness of cash flow reporting is associated with firm size, leverage, performance or liquidity. Their results indicate that cash flow reporting comprehensiveness is positively associated with firm size and negatively related to firm return on sales. The positive association of firm size is explained by a greater demand for financial information (e.g., by analysts and investors) for larger firms. The negative result on return on sales is inconsistent with the authors' hypothesis that more profitable firms would provide greater disclosure.

Following Wallace, Choudhury and Adhikari (1999) we calculate measures of: firm size (i.e., total assets and sales), leverage, (i.e., non-current liabilities divided by total assets and long-

\footnotetext{
${ }^{3}$ Page 65, Woodside Petroluem Limited 2008 Annual Report.

${ }^{4}$ Page 171, BHP Billiton Annual Report 2008.

${ }^{5}$ The companies were contacted both by telephone and email.
} 
term borrowings divided by total assets), performance (i.e., profit margin, return on equity), liquidity (i.e., current ratio) and the difference between net profit and OCF (i.e. net profit after tax minus OCF divided by total assets) for the nine companies that moved to reporting OCF using the indirect method. These items are calculated for the financial years 2006 through 2009. The details of these items are presented in Table 3 for each company. The year each company changed to the indirect method is indicated by bold italic typeface. No distinct pattern can be observed in the financial information for the year of the change in accounting disclosure. It is interesting to note however that of the nine companies that changed to the indirect format, for eight of these firms the difference between net profit after tax and OCF in the year of the switch became less negative/more positive.

\section{INSERT TABLE 3 HERE}

Our next step is to examine if the firms that switched to indirect OCF reporting have a different financial profile to their industry counterparts. To conduct this analysis we match each of the change companies within industry to two control firms: the next largest and next smallest firms as measured by total assets. ${ }^{6}$ This matching process is undertaken for the sample firms using the year in which each company switched to presenting OCF using the indirect method. ${ }^{7}$ We then calculate the same financial measures as presented in Table 3 for these control firms. The median of these ratios is then statistically compared to the median of the change firms using a Wilcoxon signed ranks test. The results of this comparison are presented in Table 4.

\section{INSERT TABLE 4 HERE}

\footnotetext{
${ }^{6}$ Where the changing firm in the sample is the largest firm in the industry, the $2^{\text {nd }}$ and $3^{\text {rd }}$ largest firms in the industry by total assets are chosen as the controls.

${ }^{7}$ The Aspect Huntley FinAnalysis database is used as the source of financial information for the control firms.
} 
The results in Table 4 indicate there are no significant differences for these financial measures between the change firms and their controls. This indicates that the decision to switch methods of presenting OCF is not motivated by differences in leverage, performance or liquidity to size matched industry controls.

\section{Conclusion}

This study examined whether ASX listed companies elected to switch their disclosure of OCF from the direct to the indirect method following the amendment of AASB 107 in 2007. The results indicate that only nine companies elected to use the indirect method between 2007 and 2009 and the financial characteristics of these companies are not different to size and industry matched controls. Our findings stand in contrast to overseas evidence that indicate firms tend to adopt the indirect method when there is a choice. The difference in results likely occurs because Australian firms had already developed reporting systems to collect information to use the direct method. The low uptake of the indirect method in Australia is likely to be welcomed by the AASB as they have expressed a distinct preference for the use of the direct method. Additionally, as prior research indicates that the direct method provides superior information for forecasting future cash flows and performance the continued disclosure of direct cash flow information by the vast majority of Australian firms will maintain the usefulness of the operating cash flow information. It will be interesting to examine in the future whether additional Australian firms choose to switch to disclosing OCF using the indirect method. 


\section{References}

Accounting Standards Board, 1996, FRS 1 Cash Flow Statements, London.

Arthur, N., Cheng, M., and Czernkowski, R., 2010, 'Cash flow disaggregation and the prediction of future earnings', Accounting and Finance, 50, 1: 1-30.

Australian Accounting Standards Board, 1997, AASB 1026: Statement of Cash Flows, Melbourne.

Australian Accounting Standards Board, 2005, AASB 107: Cash flow statements, Melbourne. Australian Accounting Standards Board, 2007, AASB 2007-4: Amendments to Australian Accounting Standards arising from ED 151 and other amendments, Melbourne.

Australian Accounting Standards Board and Financial Reporting Standards Board of the New Zealand Institute of Chartered Accountants, 2010, AASB Exposure Draft 200A and FRSB Exposure Draft 121: Proposals to harmonise Australian and New Zealand Standards in relation to entities applying IFRSs as adopted in Australia and New Zealand, Melbourne and Wellington.

Bahnson, P., Miller, P., and Budge, B., 1996, 'Non-articulation in cash flow statements and implications for education, research and practice', Accounting Horizons,10, 4: 1-16.

Bradbury, M., 2011, 'Direct or indirect cash flow statements?,' Australian Accounting Review, 21, 2: 124-130.

Brahmasrene, T., Strupeck, D., and Whitten, D., 2004, 'Examining preferences in cash flow statement format', The CPA Journal, 74, October: 58-60.

Clinch, G, Sidhu, B., and Sin, S., 2002, 'The usefulness of direct and indirect cash flow disclosures', Review of Accounting Studies, 7, 4: 383-404.

Financial Accounting Standards Board, 1987, SFAS 95 Statement of Cash Flows, Stamford.

Goyal, M., 2004, 'A survey on popularity of the direct method of cashflow reporting', The Journal of Applied Management Accounting Research, 2, 2: 41-52.

International Accounting Standards Board, 2005, IAS 107: Cash flow statements, London.

Jones, S., and Ratnatunga, J., 1997, 'The decision usefulness of cash-flow statements by Australian reporting entities: Some further evidence', British Accounting Review 29, 1: 6785.

Jones, S., Romano, C., and Smyrnios, K., 1995, 'An evaluation of the decision usefulness of cash flow statements by Australian reporting entities', Accounting and Business Research, 25, 98: 115-129. 
Jones, S., Sharma, R., and Mock, K., 1998, 'Managerial evaluations of the relevance of cash vs accrual-based financial reports in the Australian food industry', Australian Accounting Review, 8, 16: 51-58.

Krishnan, G., and Largay, J., 2000, 'The predictive ability of direct method cash flow information', Journal of Business Finance \& Accounting, 27, 1\&2: 215-245.

McEnroe, J., 1996, ‘An examination of attitudes involving cash flow accounting: Implications for the content of cash flow statements', The International Journal of Accounting, 31, 2: 161-174.

Orpurt, S., and Zang, Y., 2009, 'Do direct cash flow disclosures help predict future operating cash flows and earnings?’ The Accounting Review, 84, 3: 893-935.

Wallace, R., Choudhury, M., and Pendlebury, M., 1997, 'Cash flow statements: An international comparison of regulatory positions', The International Journal of Accounting, 32, 1: 1-22.

Wallace, R., Choudhury, M., and Adhikari, A., 1999, 'The comprehensiveness of cash flow reporting in the United Kingdom: Some characteristics and firm-specific determinants', The International Journal of Accounting, 34, 3: 311-347. 
Table 1

\section{Number of ASX listed entities using the indirect method for OCF}

This table presents statistics on the number of Australian Securities Exchange (ASX) listed entities reporting operating cash flow (OCF) using the indirect method for the 2006 through 2009 financial years.

\begin{tabular}{lcccc}
\hline Year & 2006 & 2007 & 2008 & 2009 \\
\hline $\begin{array}{l}\text { Number of entities on the ASX with } \\
\text { financial reports on FinAnalysis }\end{array}$ & 1,918 & 2,129 & 2,126 & 2,105 \\
$\begin{array}{l}\text { Number of entities presenting OCF using } \\
\text { the indirect method }\end{array}$ & 23 & 34 & 41 & 44 \\
$\begin{array}{l}\text { Indirect OCF entities partitioned by } \\
\text { standards applied in preparation of } \\
\text { financial report }\end{array}$ & & & & \\
$\quad \begin{array}{l}\text { Using Australian standards } \\
\text { Using non-Australian standards }\end{array}$ & 0 & 3 & 9 & 9 \\
& 23 & 31 & 32 & 35 \\
\hline
\end{tabular}


Table 2

\section{Listed entities using Australian accounting standards switching to the indirect method of reporting $\mathrm{OCF}$}

This table presents the names of Australian Securities Exchange (ASX) listed entities using Australian accounting standards that switched to reporting operating cash flow (OCF) using the indirect method between the 2006 and 2009 financial years.

\begin{tabular}{|c|c|c|c|c|c|}
\hline Name and ASX Code & Industry & 2006 & 2007 & 2008 & 2009 \\
\hline Amcor Limited (AMC) & Materials & Direct & Indirect & Indirect & Indirect \\
\hline BHP Billiton Limited (BHP) & Materials & Direct & Direct & Indirect & Indirect \\
\hline $\begin{array}{l}\text { Boart Longyear Limited } \\
\text { (BLY) }\end{array}$ & Industrials & $\begin{array}{l}\text { Not } \\
\text { listed }\end{array}$ & Direct & Indirect & Indirect \\
\hline Data3 Limited (DTL) & $\begin{array}{l}\text { Information } \\
\text { Technology }\end{array}$ & Direct & Indirect & Indirect & Indirect \\
\hline Infigen Energy (IFN) & Utilities & Direct & Indirect & Indirect & Indirect \\
\hline Novogen Limited (NRT) & Health care & Direct & Direct & Indirect & Indirect \\
\hline Skilled Group Limited (SKE) & $\begin{array}{c}\text { Commercial } \\
\text { and } \\
\text { professional } \\
\text { services }\end{array}$ & Direct & Direct & Indirect & Indirect \\
\hline $\begin{array}{l}\text { United Overseas Australia } \\
\text { Limited (UOS) }\end{array}$ & Financials & Direct & Direct & Indirect & Indirect \\
\hline $\begin{array}{l}\text { Woodside Petroleum Limited } \\
\text { (WPL) }\end{array}$ & Energy & Direct & Direct & Indirect & Indirect \\
\hline
\end{tabular}




\section{Table 3}

\section{Selected financial information for listed entities using Australian accounting standards switching to the indirect method of reporting OCF}

This table presents information on firm size, leverage, performance, liquidity and the difference between net profit after tax and operating cash flow (OCF) for Australian Securities Exchange listed entities using Australian accounting standards that switched to using the indirect method for presenting OCF between 2006 and 2009. Data for the year of the switch are indicated in bold and italics.

\begin{tabular}{|c|c|c|c|c|}
\hline Year & 2006 & 2007 & 2008 & 2009 \\
\hline \multicolumn{5}{|l|}{ Amcor } \\
\hline Size (Assets - \$'000) & $10,155,500$ & $9,142,300$ & $8,069,900$ & $8,446,000$ \\
\hline $\begin{array}{l}\text { Size (Sales - \$'000) } \\
\text { Leverage (Non-current liabilities/Total }\end{array}$ & $10,222,800$ & $9,960,100$ & $9,234,900$ & $9,535,400$ \\
\hline $\begin{array}{l}\text { Assets) } \\
\text { Leverage (Long-term borrowings/Total }\end{array}$ & $26.72 \%$ & $22.31 \%$ & $28.81 \%$ & $28.63 \%$ \\
\hline Assets) & $20.53 \%$ & $17.73 \%$ & $22.72 \%$ & $22.21 \%$ \\
\hline Profit margin(Profit after tax/Sales) & $3.71 \%$ & $5.47 \%$ & $2.89 \%$ & $2.28 \%$ \\
\hline Return on equity (Net profit after tax/Equity) & $9.82 \%$ & $15.22 \%$ & $8.87 \%$ & $7.08 \%$ \\
\hline Liquidity (Current assets/Current Liabilities) & 0.89 & 0.96 & 0.95 & 0.79 \\
\hline $\begin{array}{l}\text { Difference between net profit after tax and } \\
\text { cash from operations divided by assets }\end{array}$ & $-5.76 \%$ & $-4.39 \%$ & $-78.61 \%$ & $-5.40 \%$ \\
\hline \multicolumn{5}{|l|}{ BHP } \\
\hline Size (Assets - \$'000) & $48,516,000$ & $58,168,000$ & $75,889,000$ & $78,770,000$ \\
\hline $\begin{array}{l}\text { Size (Sales - } \$ 000 \text { ) } \\
\text { Leverage (Non-current liabilities/Total }\end{array}$ & $32,153,000$ & $39,498,000$ & $59,473,000$ & $50,211,000$ \\
\hline $\begin{array}{l}\text { Assets) } \\
\text { Leverage (Long-term borrowings/Total }\end{array}$ & $49.59 \%$ & $48.57 \%$ & $27.00 \%$ & $33.27 \%$ \\
\hline Assets) & $15.76 \%$ & $15.97 \%$ & $12.17 \%$ & $19.46 \%$ \\
\hline Profit margin(Profit after tax/Sales) & $32.76 \%$ & $34.17 \%$ & $26.84 \%$ & $12.62 \%$ \\
\hline quity (Net profit after tax/Equity) & $43.08 \%$ & $45.11 \%$ & $41.01 \%$ & $15.57 \%$ \\
\hline Liquidity (Current assets/Current Liabilities) & 0.99 & 1.08 & 1.32 & 1.90 \\
\hline $\begin{array}{l}\text { Difference between net profit after tax and } \\
\text { cash from operations divided by assets }\end{array}$ & $0.12 \%$ & $-3.61 \%$ & $-2.90 \%$ & $-15.90 \%$ \\
\hline \multicolumn{5}{|l|}{ Boart Longyear } \\
\hline Size (Assets - \$'000) & $\mathrm{n} / \mathrm{a}$ & $1,212,345$ & $1,294,007$ & $1,365,838$ \\
\hline $\begin{array}{l}\text { Size (Sales - \$'000) } \\
\text { Leverage (Non-current liabilities/Total }\end{array}$ & $\mathrm{n} / \mathrm{a}$ & $1,575,737$ & $1,838,538$ & 978,177 \\
\hline $\begin{array}{l}\text { Assets) } \\
\text { Leverage (Long-term borrowings/Total }\end{array}$ & $\mathrm{n} / \mathrm{a}$ & $57.20 \%$ & $68.73 \%$ & $13.73 \%$ \\
\hline Assets) & $\mathrm{n} / \mathrm{a}$ & $53.63 \%$ & $62.89 \%$ & $9.70 \%$ \\
\hline Profit margin(Profit after tax/Sales) & $\mathrm{n} / \mathrm{a}$ & $5.15 \%$ & $8.52 \%$ & $-1.52 \%$ \\
\hline Return on equity (Net profit after tax/Equity) & $\mathrm{n} / \mathrm{a}$ & $36.93 \%$ & $102.87 \%$ & $-1.59 \%$ \\
\hline Liquidity (Current assets/Current Liabilities) & $\mathrm{n} / \mathrm{a}$ & 1.89 & 1.98 & 2.01 \\
\hline $\begin{array}{l}\text { Difference between net profit after tax and } \\
\text { cash from operations divided by assets }\end{array}$ & $\mathrm{n} / \mathrm{a}$ & $-6.32 \%$ & $1.07 \%$ & $-9.67 \%$ \\
\hline
\end{tabular}


Table 3 - continued

\begin{tabular}{|c|c|c|c|c|}
\hline Year & 2006 & 2007 & 2008 & 2009 \\
\hline \multicolumn{5}{|l|}{ Data 3 Limited } \\
\hline Size (Assets - \$'000) & 59,967 & 82,003 & 102,962 & 139,203 \\
\hline $\begin{array}{l}\text { Size (Sales - \$'000) } \\
\text { Leverage (Non-current liabilities/Total }\end{array}$ & 238,968 & 284,659 & 362,858 & 529,665 \\
\hline $\begin{array}{l}\text { Assets) } \\
\text { Leverage (Long-term borrowings/Total }\end{array}$ & $1.09 \%$ & $1.00 \%$ & $0.86 \%$ & $0.62 \%$ \\
\hline Assets) & $0.00 \%$ & $0.00 \%$ & $0.00 \%$ & $0.00 \%$ \\
\hline Profit margin(Profit after tax/Sales) & $2.39 \%$ & $2.53 \%$ & $2.50 \%$ & $1.86 \%$ \\
\hline Return on equity (Net profit after tax/Equity) & $33.81 \%$ & $37.73 \%$ & $39.74 \%$ & $42.14 \%$ \\
\hline Liquidity (Current assets/Current Liabilities) & 1.260 & 1.216 & 1.176 & 1.141 \\
\hline $\begin{array}{l}\text { Difference between net profit after tax and } \\
\text { cash from operations divided by assets }\end{array}$ & $-4.08 \%$ & $-1.05 \%$ & $0.70 \%$ & $-6.98 \%$ \\
\hline \multicolumn{5}{|l|}{ Infigen Energy Limited } \\
\hline Size (Assets - \$'000) & $1,413,035$ & $2,387,475$ & $6,757,430$ & $4,407,781$ \\
\hline $\begin{array}{l}\text { Size (Sales - \$'000) } \\
\text { Leverage (Non-current liabilities/Total }\end{array}$ & 37,106 & 55,883 & 78,378 & 101,020 \\
\hline $\begin{array}{l}\text { Assets) } \\
\text { Leverage (Long-term borrowings/Total }\end{array}$ & $45.75 \%$ & $55.79 \%$ & $54.22 \%$ & $38.38 \%$ \\
\hline Assets) & $44.69 \%$ & $54.44 \%$ & $49.46 \%$ & $35.57 \%$ \\
\hline Profit margin(Profit after tax/Sales) & $-43.75 \%$ & $24.79 \%$ & $50.82 \%$ & $190.99 \%$ \\
\hline Return on equity (Net profit after tax/Equity) & $-2.44 \%$ & $1.84 \%$ & $3.07 \%$ & $20.97 \%$ \\
\hline Liquidity (Current assets/Current Liabilities) & 3.60 & 1.64 & 0.95 & 2.11 \\
\hline $\begin{array}{l}\text { Difference between net profit after tax and } \\
\text { cash from operations divided by assets }\end{array}$ & $-2.15 \%$ & $-3.02 \%$ & $-2.18 \%$ & $0.55 \%$ \\
\hline \multicolumn{5}{|l|}{ Novogen Limited } \\
\hline Size (Assets - \$'000) & 51,098 & 51,357 & 43,401 & 37,842 \\
\hline $\begin{array}{l}\text { Size (Sales - } \$ 000) \\
\text { Leverage (Non-current liabilities/Total }\end{array}$ & 17,445 & 17,295 & 13,283 & 11,147 \\
\hline $\begin{array}{l}\text { Assets) } \\
\text { Leverage (Long-term borrowings/Total }\end{array}$ & $0.66 \%$ & $0.53 \%$ & $0.89 \%$ & $0.62 \%$ \\
\hline Assets) & $0.00 \%$ & $0.00 \%$ & $0.00 \%$ & $0.00 \%$ \\
\hline Profit margin(Profit after tax/Sales) & $-102.68 \%$ & $-140.48 \%$ & $-186.53 \%$ & $-213.39 \%$ \\
\hline Return on equity (Net profit after tax/Equity) & $-40.18 \%$ & $-54.44 \%$ & $-69.53 \%$ & $-82.67 \%$ \\
\hline Liquidity (Current assets/Current Liabilities) & 7.08 & 7.82 & 5.80 & 4.24 \\
\hline $\begin{array}{l}\text { Difference between net profit after tax and } \\
\text { cash from operations divided by assets }\end{array}$ & $-6.80 \%$ & $-18.86 \%$ & $-10.75 \%$ & $-8.42 \%$ \\
\hline
\end{tabular}


Table 3 - continued

\begin{tabular}{|c|c|c|c|c|}
\hline Year & 2006 & 2007 & 2008 & 2009 \\
\hline \multicolumn{5}{|l|}{ Skilled Group Limited } \\
\hline Size (Assets - \$'000) & 235,188 & 487,737 & 760,905 & 703,548 \\
\hline $\begin{array}{l}\text { Size (Sales - \$'000) } \\
\text { Leverage (Non-current liabilities/Total }\end{array}$ & 968,382 & $1,384,811$ & $1,929,530$ & $1,943,258$ \\
\hline $\begin{array}{l}\text { Assets) } \\
\text { Leverage (Long-term borrowings/Total }\end{array}$ & $5.24 \%$ & $24.10 \%$ & $38.55 \%$ & $45.34 \%$ \\
\hline Assets) & $1.03 \%$ & $20.40 \%$ & $29.83 \%$ & $37.06 \%$ \\
\hline Profit margin(Profit after tax/Sales) & $2.55 \%$ & $2.09 \%$ & $2.04 \%$ & $1.45 \%$ \\
\hline Return on equity (Net profit after tax/Equity) & $21.28 \%$ & $20.89 \%$ & $16.76 \%$ & $12.42 \%$ \\
\hline Liquidity (Current assets/Current Liabilities) & 1.22 & 0.89 & 1.27 & 1.49 \\
\hline $\begin{array}{l}\text { Difference between net profit after tax and } \\
\text { cash from operations divided by assets }\end{array}$ & $-5.48 \%$ & $-2.80 \%$ & $3.24 \%$ & $-13.28 \%$ \\
\hline \multicolumn{5}{|l|}{ United Overseas Australia Limited } \\
\hline Size (Assets - \$'000) & 340,535 & 461,051 & 663,547 & 641,150 \\
\hline $\begin{array}{l}\text { Size (Sales - } \$ 000) \\
\text { Leverage (Non-current liabilities/Total }\end{array}$ & 36,865 & 30,634 & 174,305 & 152,179 \\
\hline $\begin{array}{l}\text { Assets) } \\
\text { Leverage (Long-term borrowings/Total }\end{array}$ & $1.81 \%$ & $2.55 \%$ & $1.65 \%$ & $2.02 \%$ \\
\hline Assets) & $1.09 \%$ & $2.09 \%$ & $1.19 \%$ & $0.40 \%$ \\
\hline Profit & $67.00 \%$ & $94.60 \%$ & $22.51 \%$ & $18.57 \%$ \\
\hline Returl & $9.41 \%$ & $7.81 \%$ & $7.63 \%$ & $5.39 \%$ \\
\hline Liquidity (Current & 2.01 & 2.03 & 1.94 & 2.01 \\
\hline $\begin{array}{l}\text { Difference between net profit after tax and } \\
\text { cash from operations divided by assets }\end{array}$ & $-3.78 \%$ & $-2.97 \%$ & $3.70 \%$ & $-14.57 \%$ \\
\hline \multicolumn{5}{|l|}{ Woodside Petroluem Limited } \\
\hline Size (Assets - \$'000) & $8,968,700$ & $9,730,000$ & $14,929,000$ & $19,874,000$ \\
\hline $\begin{array}{l}\text { Size (Sales - \$'000) } \\
\text { Leverage (Non-current liabilities/Total }\end{array}$ & $3,475,500$ & $3,841,400$ & $5,990,000$ & $4,352,000$ \\
\hline $\begin{array}{l}\text { Assets) } \\
\text { Leverage (Long-term borrowings/Total }\end{array}$ & $37.69 \%$ & $27.46 \%$ & $37.74 \%$ & $38.90 \%$ \\
\hline Assets) & $16.80 \%$ & $6.35 \%$ & $19.81 \%$ & $27.82 \%$ \\
\hline Profit margin(Profit afte & $41.06 \%$ & $26.82 \%$ & $29.82 \%$ & $41.77 \%$ \\
\hline Return on equity (Net profit after tax/Equity) & $33.96 \%$ & $20.22 \%$ & $25.76 \%$ & $17.52 \%$ \\
\hline Liquidity (Current assets/Current Liabilities) & 0.87 & 0.41 & 0.36 & 1.53 \\
\hline $\begin{array}{l}\text { Difference between net profit after tax and } \\
\text { cash from operations divided by assets }\end{array}$ & $-11.28 \%$ & $-19.91 \%$ & $-13.38 \%$ & $-0.21 \%$ \\
\hline
\end{tabular}




\section{Table 4}

\section{Selected financial information for firms that elected to use the indirect method of presenting OCF compared with size matched controls}

This table presents the median of firm size, leverage, performance, liquidity and the difference between net profit after tax and operating cash flow (OCF) for the year that nine ASX listed entities elected to switch to using the indirect method for presenting OCF. Using a Wilcoxon signed ranked test this median is compared with $\mathrm{t}$ This table presents the median of firm size, leverage, performance, liquidity and the difference between net profit after tax and operating cash flow (OCF) for the year that nine ASX listed entities elected to switch to using the indirect method for presenting OCF. Using a Wilcoxon signed ranked test this median is compared with the median for a control group matched to each of the change firms by industry and size.

\begin{tabular}{|c|c|c|c|}
\hline Variable & & $\begin{array}{l}\text { Matched firms } \\
\text { by industry } \\
\text { and size } \\
(\mathrm{n}=18)\end{array}$ & $\begin{array}{l}\text { Changers } \\
(n=9)\end{array}$ \\
\hline \multirow[t]{2}{*}{ Size (Total Assets - \$’000) } & median & 591,429 & $1,294,007$ \\
\hline & $p$-value & \multicolumn{2}{|c|}{0.5316} \\
\hline \multirow[t]{2}{*}{ Size (Sales - \$’000) } & median & $1,378,545$ & $1,838,538$ \\
\hline & $p$-value & \multicolumn{2}{|c|}{0.4203} \\
\hline \multirow{2}{*}{$\begin{array}{l}\text { Leverage } \\
\text { (Non-current Liabilities/Total Assets) }\end{array}$} & median & 0.337 & 0.270 \\
\hline & $p$-value & \multicolumn{2}{|c|}{0.5918} \\
\hline \multirow{2}{*}{$\begin{array}{l}\text { Leverage } \\
\text { (Long-term borrowings /Total Assets) }\end{array}$} & median & 0.247 & 0.177 \\
\hline & $p$-value & \multicolumn{2}{|c|}{0.6753} \\
\hline \multirow{2}{*}{$\begin{array}{l}\text { Profit margin } \\
\text { (Net profit after tax/Sales) }\end{array}$} & median & 0.065 & 0.085 \\
\hline & $p$-value & \multicolumn{2}{|c|}{0.5858} \\
\hline \multirow{2}{*}{$\begin{array}{l}\text { Return on equity } \\
\text { (Net profit after tax /Equity) }\end{array}$} & median & 0.099 & 0.168 \\
\hline & $p$-value & \multicolumn{2}{|c|}{0.7886} \\
\hline \multirow[t]{2}{*}{ Liquidity (Current assets/Current liabilities) } & median & 1.455 & 1.320 \\
\hline & $p$-value & \multicolumn{2}{|c|}{0.2835} \\
\hline \multirow{2}{*}{$\begin{array}{l}\text { Difference between net profit after tax and } \\
\text { cash from operations divided by assets }\end{array}$} & median & -0.036 & -0.029 \\
\hline & $p$-value & \multicolumn{2}{|c|}{0.7886} \\
\hline
\end{tabular}

